\title{
Ownership Structure, Financial Decisions, and Institutional Setting: An International Analysis through Simultaneous Equations
}

\author{
Félix J. López-Iturriaga ${ }^{1,2}$ and Juan Antonio Rodríguez-Sanz ${ }^{2}$ \\ ${ }^{1}$ Facultad de CC. EE. y Empresariales, Universidad de Valladolid, 47011 Valladolid, Spain \\ ${ }^{2}$ School of Business \& Economics, University of Valladolid, Avda. Valle del Esgueva, 6, 47011 Valladolid, Spain
}

Correspondence should be addressed to Félix J. López-Iturriaga, flopez@eco.uva.es

Received 2 April 2012; Revised 3 July 2012; Accepted 5 July 2012

Academic Editor: Evžen Kočenda

Copyright ( $) 2012$ F. J. López-Iturriaga and J. A. Rodríguez-Sanz. This is an open access article distributed under the Creative Commons Attribution License, which permits unrestricted use, distribution, and reproduction in any medium, provided the original work is properly cited.

\begin{abstract}
We analyze the mutual relations among firms' capital structure, ownership structure, and valuation. Through the estimation of a system of simultaneous equations for a sample of 1,130 firms from 16 countries from both the common law and the civil law environments, our results confirm the differential effect of ownership structure on firms' value in each setting. Whereas in civil law firms the higher ownership concentration results in an entrenchment and an alignment effect, in the common law firms higher ownership concentration increases the value of the firm. Second, we corroborate the endogeneity of ownership structure since we find that ownership structure is affected by the value of the firm and by the capital structure. Third, our results suggest that corporate finance decisions are taken simultaneously with other mechanisms of corporate governance and conditional on firms' valuation.
\end{abstract}

\section{Introduction}

In latest decades an increasing number of papers have addressed the interrelation among the ownership structure, corporate finance decisions, and the value of the firm. Much of this literature has shown the relevance of both the ownership structure and the capital structure for value creation due to the separation between corporate ownership and control, the asymmetric information problems, and the conflicts of interests among stakeholders [1-4]. Taken together, this research has highlighted the role of these mechanisms of corporate control both as a mean of managerial discipline $[5,6]$ and as an informative signal to capital markets [7].

Most of the research has addressed the relation between corporate financial decisions and agency problems in isolation taken into account only one mechanism of corporate control [8-10]. Notwithstanding, in latest years some authors have analyzed the simultaneous effect of several of these factors. These authors have focused on the relation between corporate value and ownership structure [11-13], with other authors expanding the models to introduce some key financial decisions such as the financial leverage, the dividend policy, or the investment structure [14-16]. Most of this research has in common that both financial decisions and ownership structure may modify the managerial incentives and arrives to conclusions to some extent conflicting with the first group of papers. This divergence of results suggests that systems of simultaneous equations are one of the most suitable procedures to identify correctly the interrelation among corporate ownership, corporate finance, and corporate value [15, 17-19].

An additional advantage of simultaneous equations is the ability to deal with the possible endogeneity of variables [20, 21]. According to the endogeneity idea, ownership structure is not only a determinant of corporate finance but also an outcome of corporate financial decisions and of corporate value, so that financial decisions should be no longer studied isolated of other issues of corporate finance but in a joint approach $[9,16]$.

Running parallel to this process, the influence of the legal and institutional setting is one of the topics in finance which draws an increasing attention. The origin of the legal 
system of each country sheds some light on several issues such as the ownership structure, the corporate governance or the orientation to capital markets [22-24]. The notable international differences across countries suggest the need of a compared analysis in which the legal origin of each company is explicitly taken into account.

Our research tries to join at the same time both directions of research: the one concerning the interrelation of corporate value and financial decisions, and the one concerning the international legal approach of finance. We analyze 1,130 firms from 16 countries both from the civil law and the common law systems: France, Italy, Portugal, Spain, the Netherlands, Belgium, Greece, Germany, Japan, Austria, Norway, Sweden, Finland, Australia, USA, and the UK. We wonder three questions: (1) is corporate ownership structure endogeneously affected by corporate value? (2) to which extent are corporate financial decisions and the ownership structure mutually related and linked to the corporate value? (3) does all this set of relations depend on the legal and institutional framework?

Our results suggest, first, a significantly different effect of ownership concentration on the value of the firm. Whereas in the civil law environment we find a nonlinear relation combining both the entrenchment and the alignment of interests, in common law countries we detect a positive relation between corporate value and ownership concentration. For common law firms we find that the entrenchment and alignment of managerial interests applies, with a cubical effect of managerial ownership on firm's value. Second, consistent with the endogeneity approach, we find that the ownership structure both impacts and is impacted by corporate value. Third, endogeneity also applies to capital structure, so that the ownership structure, the capital structure and the corporate value must be analyzed simultaneously.

We contribute to the literature by expanding the analysis framework. Previous research has not yet analyzed these decisions simultaneously [25], has omitted the effect of the ownership structure [20], has omitted the effect of institutional differences $[12,26]$, or has neglected the effect of corporate finance [13]. Thus, our research addresses the mutual interactions among corporate finance, corporate ownership, and corporate value taking explicitly into account the moderating effect of the legal and institutional setting.

The paper is divided into five sections. Section 2 analyzes previous research. Section 3 describes the empirical analysis: we explain the sample and variables used, and we explain the empirical method. Section 4 reports the empirical results and we assess the robustness of our results. In the final section some conclusions are drawn from the most outstanding results.

\section{Theoretical Background}

2.1. Ownership Structure and Corporate Value. A great deal of the analysis of the relation between ownership structure and corporate value is founded on the well-known hypotheses of alignment and entrenchment [3]. The underlying idea in these hypotheses is the agency conflict that arises between shareholders and managers in highly diluted ownership structures. Although the managerial relation has drawn most of the attention, in latest years literature has increasingly focused on the possible conflict of interests between large dominant shareholders and minority shareholders [27-31]. In addition, the type of owner has recently drawn the attention since his/her ability to monitor can depend on the experience and incentives. For instance, Estrin et al. [32] find that in China and in some European Union accessing countries the privatization to foreign owners has been more efficient than the privatization to domestic owners.

Theoretically, the ownership concentration increases managerial monitoring. Nevertheless, a relatively concentrated ownership structure could result in ambiguous incentives for large shareholders since they could try to use their power to extract private benefits. Furthermore, some characteristics of the ownership structure such as crossing shares and pyramidal structures have exacerbated this problem by increasing these shareholders' control rights far above their cash flow rights [33-35]. Therefore, a nonlinear relation between corporate value and large shareholders stakes can arise.

Although the literature has traditionally assumed that firm's value is an outcome of the ownership structure, recent studies have proposed that the ownership structure can be the consequence of a number of corporate decisions too [ 9 , $11,17]$. Thus, the endogeneity issue arises since ownership structure can be affected by the firm's value [20, 36, 37], and the unidirectional regression models may no longer be the most suitable ones to test the effect of ownership structure $[26,38]$. Nevertheless, the sign of this relation is not clear with some authors claiming a negative relation [39] whereas other authors support a positive relation [40-42].

Most of this research has been carried out in the socalled common law countries and just in the latest years the approach has internationalized [43]. The characteristics of the common law corporate system are a better legal protection of investors, a more dispersed ownership structure, and the lack of controlling shareholders [23, 30, $44,45]$. Thus, one could wonder whether the same kind of relation applies to the civil law environment. In this framework, investors have worse legal protection and the corporate control mechanisms operate differently. Corporate ownership is usually more concentrated with some large shareholders having monitoring capacity (families, institutional investors, crossing shareholdings, pyramids, etc.). These large shareholders may be reluctant to share their benefits of control with minority shareholders and could try to reach an optimal stake in the ownership.

Consequently, the possible private benefits of control can lead to a different relations among ownership concentration, managerial ownership, and corporate value in each legal environment $[13,43,46]$. In fact, Demsetz and Villalonga [11], Thomsen et al. [13] and Cho [20] show that the value of the firm can have some influence on the ownership structure and underline the accuracy of simultaneous equations to address this topic.

Hence, previous literature advises to take into account the possible endogeneity of the ownership structure, the 
ambiguity of the causal relation with the value of the firm, and the role of the institutional framework. In the same vein, the method of simultaneous equations seems to be the most suitable one to address all this set of relations. Nevertheless, this analysis would be incomplete if we do not introduce corporate financial decisions.

2.2. Ownership Structure and Capital Structure. The capital structure is a mechanism of corporate governance additional to the ownership structure [47]. Both of them have in common their informational potential since they can convey expectations about the investment projects, and they can modify managerial incentives. From an agency point of view, debt financing increases the control on managers [48] at the same time that can work as a signaling mechanism to capital markets [7] too. From this point of view, the capital structure and the ownership structure are substitutive mechanisms of corporate governance, and one should expect a negative relation between them.

Nevertheless, too concentrated ownership can result in an entrenchment effect and the need of more managerial monitoring [3]. Since debt financing may act as a managerial control mechanism, both mechanisms could be viewed as complementary ones and one could expect a positive relation. While Myers and Majluf [41] predict a negative relation between managerial ownership and debt, Kim and Sorensen [49] lend support to the idea of complementarity detecting a positive relation between ownership structure and firm financial status.

There is a discussion about the direction of causality, with some authors supporting the ownership structure as a consequence of the capital structure [50] and other authors considering the ownership structure as a determinant of the capital structure $[15,16]$. In any case, such complex set of possible interrelations makes difficult to isolate one direction of influence and suggests that the final equilibrium is achieved through the simultaneous interaction of all the mechanisms [8]. This approach is corroborated by the literature on the simultaneity between corporate finance and corporate ownership. In this vein, Chen and Steiner [14] and Fenn and Liang [51] find that insider ownership is affected by financing decisions. In terms of alignment and entrenchment, the ownership structure can have a nonlinear effect on financial leverage $[8,26]$.

In sum, given the relevance of corporate financial decisions, the capital structure should be included in a system of simultaneous equations along with the corporate ownership and the firm value in order to explore their interrelations and the most significant differences between the civil law and the common law environment.

\section{Data, Variables, and Method}

Consistently with the abovementioned theoretical background, we propose a multiple causality direction between the value of the firm, the ownership structure, and the capital structure. In addition, the relation can be conditioned by the institutional setting and, to some extent, by the
TABLE 1: Sample composition by countries.

\begin{tabular}{lcc}
\hline & Firms & Observations \\
\hline Civil law & 628 & 2,723 \\
French tradition & 344 & 1,433 \\
France & 110 & 469 \\
Italy & 74 & 284 \\
Portugal & 17 & 72 \\
Spain & 76 & 331 \\
The Netherlands & 31 & 138 \\
Belgium & 13 & 56 \\
Greece & 23 & 83 \\
German tradition & 238 & 1,113 \\
Germany & 94 & 417 \\
Japan & 129 & 613 \\
Austria & 15 & 83 \\
Scandinavian tradition & 46 & 177 \\
Norway & 14 & 51 \\
Sweden & 13 & 61 \\
Finland & 19 & 65 \\
\hline Common law & 502 & 2,145 \\
Australia & 63 & 224 \\
USA & 256 & 1,186 \\
UK & 183 & 735 \\
\hline
\end{tabular}

profile of agency problems prevailing in each setting. From a methodological point of view, we do not propose explicit hypotheses, but we try to find empirical patterns coherent with the theoretical background, we relate our results to previous research, and we emphasize the contributions of our research.

3.1. Data. We have collected information on financial statements (balance sheet and income statement), on equity market value and on ownership structure from Thomson ONE Banker. Due to operational constraints given the complexity of the information about ownership structure, we have not been able to study all the quoted firms from the sample countries but have had to take a sample of firms from each country to be analyzed. The number of firms from each country has been determined according to the relative economic importance of the country. As shown in Table 1, our sample includes 4,868 observations from 1,130 firms from 16 nations from Europe, Asia, Australia, and America between 2000 and 2006. Evidently, there are differences among the number of firms from each country given the different size of the country and the importance of capital markets. The classification of the institutional setting is based on the Law \& Finance approach, so that firms belong either to the civil law or to the common law system. Civil law firms account for 55.5 percent of firms and for 55.9 percent of observations, whereas common law firms account for 44.5 percent of firms and 44.1 percent of observations.

3.2. Variables. The dependent variables can be classified into three corporate issues: firm value, ownership structure, and capital structure. Market value has been defined as the ratio 
of equity market value to book value (MBE). This variable has been widely used in previous research and enhances the comparability of our results [52-56].

Ownership structure has been operationalized on the basis of the ownership concentration, the identity of the largest shareholders, and the managerial ownership. We define the ownership concentration with two variables: the proportion of shares held by the largest shareholder (C1) and a Herfindahl index of concentration in the hands of the five largest shareholders (HERF). We use two variables because, although HERF variable is a more comprehensive metric of ownership concentration [57-59], it suffers from severe limitations for nonlinear specifications of the ownership structure. Concerning the identity of the largest shareholder, the information provided by Thomson ONE Banker allows us to scrutinize carefully the nature of the shareholders. Accordingly, we divide the largest shareholders into two groups: strategic entities and investment managers. Strategic entities are nonfinancial corporations, individual investors, and families that hold a stake in a firm for the sake of strategic interests and controlling purposes. Investment managers are banks, trusts, mutual and pension funds, insurance companies, and venture capital whose main orientation is not strategic but rather focused on financial performance. Managerial ownership has been defined as INS, the proportion of shares owned by inside shareholders [3]. We have defined LEV to measure financial leverage as the ratio of the book value of debt to the book value of equity [14].

We also control for the factors potentially affecting corporate financial decisions, the ownership structure or the firm market value [60]. First, we control for the firm size (SIZE), defined as the log of total assets. Second, we control for the performance of the firm through ROA or the return on assets. Third, we control for growth opportunities (OPORT) with the intangible assets to total long-term assets ratio $[61,62]$. Fourth, we control for the risk of the firm with the variance of the ROA from the beginning of the analyzed period $[63,64]$. To control for time, country, and industry effects, we define a set of year-dummy and country-dummy variables as well as a set of one-digit SIC classification industry-dummy variables. In addition, since there can be some differences across the analysed countries in terms of their development, we also control for such effects through a dummy variable (RICH). This variable is defined according to the information on GDP per capita provided by the International Monetary Fund [65]. Consistent with this dataset the countries above the median value are Australia, Austria, Belgium, Finland, the Netherlands, Japan, Norway, Sweden, and the USA.

3.3. Method. Given our aim to analyze the possible simultaneity of financial decisions and due to the possible endogeneity of the ownership structure, we estimate a system of three simultaneous equations in which each equation is related to one of the issues. Thus, the dependent variable in the first equation is the value of the firm, in the second equation the ownership concentration, and in the third equation the capital structure.
The firm's value depends on the financial leverage, and on the ownership structure (measured both by the ownership concentration and the managerial ownership). Due to nonlinear effects, we include both variables in linear and squared terms. We also control for the usual factors. The second equation is aimed to explain the ownership concentration (HERF). Given the possibility of endogeneous relations, this variable depends on the value of the firm, on the financial leverage and on the control variables. In the third equation, capital structure depends on the other two endogeneous variables (the value of the firm and the ownership concentration) and on the control variables.

Thus, the system of three simultaneous equations can be stated as follows:

$$
\begin{aligned}
\mathrm{MBE}_{\mathrm{it}}= & \alpha_{1}+\beta_{1} \cdot \mathrm{LEV}+\beta_{2} \cdot C 1_{\mathrm{it}}+\beta_{3} \cdot \mathrm{Cl}_{\mathrm{it}}^{2} \\
& +\beta_{4} \cdot \mathrm{INS}_{\mathrm{it}}+\beta_{5} \cdot \mathrm{INS}_{\mathrm{it}}^{2}+\beta_{6} \cdot \mathrm{SIZE}_{\mathrm{it}} \\
& +\beta_{7} \cdot \mathrm{RISK}_{\mathrm{it}}+\beta_{8} \cdot \mathrm{ROA}_{\mathrm{it}}+\beta_{9} \cdot \mathrm{OPORT}_{\mathrm{it}} \\
& +\eta_{t}+\varepsilon_{\mathrm{it}}, \\
\mathrm{HERF}_{\mathrm{it}}= & \alpha_{1}+\beta_{1} \cdot \mathrm{LEV}+\beta_{2} \cdot \mathrm{MBE}_{\mathrm{it}}+\beta_{3} \cdot \mathrm{SIZE}_{\mathrm{it}} \\
& +\beta_{4} \cdot \mathrm{RISK} \mathrm{it}+\beta_{5} \cdot \mathrm{ROA}_{\mathrm{it}}+\beta_{6} \cdot \mathrm{OPORT}_{\mathrm{it}} \\
& +\eta_{t}+\varepsilon_{\mathrm{it}}, \\
\mathrm{LEV}_{\mathrm{it}}= & \alpha_{1}+\beta_{1} \cdot \mathrm{MBE}+\beta_{2} \cdot \mathrm{HERF}_{\mathrm{it}}+\beta_{3} \cdot \mathrm{SIZE}_{\mathrm{it}} \\
& +\beta_{4} \cdot \mathrm{RISK}_{\mathrm{it}}+\beta_{5} \cdot \mathrm{ROA}_{\mathrm{it}}+\beta_{6} \cdot \mathrm{OPORT}_{\mathrm{it}} \\
& +\eta_{t}+\varepsilon_{\mathrm{it}},
\end{aligned}
$$

where $\eta_{t}$ are the dummy variables for time effects and $\mathcal{E}_{\text {it }}$ is the random error. Time-dummy variables are aimed to control for macroeconomic factors that could impact on all the firms in a given moment. Given the significant differences between both institutional settings, we run the system of simultaneous equations separately for civil law and for common law firms.

The random errors are likely to be correlated across equations. Accordingly, we should not estimate each equation in isolation but run a joint test of the three equations. One of the most widely used estimation methods is the threestages least-squares method (3SLS). This procedure provides efficient estimates when error terms can be correlated across equations. In the first stage, instrumental variables are developed for all the endogeneous variables by combining the other endogeneous variables and the predetermined variables. In the second stage the estimates are computed based on the residuals of the two steps estimates for each equation. Finally, in the third step, a generalized leastsquares estimation is done using the covariance matrix of the second step and using the instrumental variables instead of the endogeneous variables. We consider as endogeneous the three, dependent variables: the firm's value, the capital structure and the ownership concentration. To avoid outliers that could bias our results, we run the outlier detection multivariate procedure $[66,67]$. This method provides a suitable dropout of outliers through a multivariate approach. 
TABle 2: Descriptive statistics.

\begin{tabular}{lcccc}
\hline Variable & Mean & Std. dev. & Min. & Max. \\
\hline MBE & 2.667 & 2.251 & 0.103 & 30.111 \\
LEV & 2.163 & 1.690 & 0.055 & 12.059 \\
C1 & 19.722 & 21.262 & 0 & 99.980 \\
INS & 12.119 & 9.893 & 0 & 79.960 \\
HERF & 0.418 & 0.168 & 0.2 & 0.990 \\
SIZE & 3.652 & 0.635 & 1.274 & 5.747 \\
ROA & 0.089 & 0.060 & -0.213 & 0.430 \\
RISK & 0.447 & 1.057 & 0 & 10.611 \\
OPORT & 0.238 & 0.913 & 0 & 0.925 \\
\hline
\end{tabular}

Given some concerns about the possible misspecification of one equation leading to biased estimates of the other equations, we provide the Hausman-Wu test [68]. This test allows checking the validity of the equation-byequation estimates against 3SLS under the null hypothesis that any endogeneity among the regressors would not have deleterious effects on the estimates. The Hausman-Wu test is distributed chi-squared with $m$ degrees of freedom, where $m$ is the number of regressors specified as endogenous in the original instrumental variables regression. As a robustness check of the effect of the institutional setting, Tables 4 and 5 report the average treatment effect by comparing outcomes from both institutional environments [69].

\section{Results}

4.1. Descriptive Analysis. Table 2 reports the mean, the standard error, the maximum, and the minimum of the main variables. In order to underline the difference across legal environments, Table 3 reports the mean value in each setting and the $P$-value for the test of means comparison between both subsamples.

As shown in Table 3, there are significant differences between the civil-law and the common-law firms. Civil-law firms have higher financial leverage, lower market valuation [70], more concentrated ownership [23], and higher managerial ownership. There are also significant differences in the control variables, with smaller firms and lower performance in the civil law setting. These firms also run less risk (which could be related to their lower performance) and have less growth opportunities.

These results are coherent with previous literature [27, 28 ] and point at the possibility of differential effects in each institutional setting and, thus, the need of a differential analysis for civil law and for common law firms.

4.2. Explanatory Analysis. In order to avoid an excessively complex presentation of the results due to the multiple interactions among variables, we will focus our analysis on the answer to the three basic questions: (1) differential influence of the ownership structure conditional on legal frameworks; (2) endogeneity of the ownership structure; (3) interdependence among the mechanisms of corporate governance.
TABLE 3: Results of the test of means comparison.

\begin{tabular}{lccc}
\hline Variable & Civil law & Common law & $P$-value \\
\hline MBE & 2.247 & 3.200 & 0.000 \\
LEV & 2.284 & 2.009 & 0.000 \\
HERF & 0.434 & 0.336 & 0.000 \\
C1 & 26.524 & 11.087 & 0.000 \\
INS & 13.736 & 9.904 & 0.000 \\
SIZE & 3.554 & 3.776 & 0.000 \\
ROA & 0.078 & 0.103 & 0.000 \\
RISK & 0.002 & 1.012 & 0.000 \\
OPORT & 0.124 & 0.344 & 0.000 \\
\hline
\end{tabular}

In Table 4, we report the estimates of the baseline model. The three upper rows are the estimates of the endogeneous variables, and below them we report the estimates of the control variables. As shown in Column (1), there is an opposite influence of ownership concentration on the value of the firm (MBE) in each legal and institutional setting. HERF variable cannot be included in the system of simultaneous equations due to the specification problems because the joint inclusion of HERF, C1, and INS would render impossible the estimation of the model. Whereas in the civil law setting the ownership concentration is nonlinearly related to the value of the firm, in the common law countries there is no relation between the ownership concentration and the value of the firm. The results in the civil-law firms can be explained on the basis of the entrenchment and the convergence effects. For low levels of ownership, the largest shareholders can try to extract private benefits, which would have a negative effect on the value of the firm. Nevertheless, for high enought owership concentration (the turning point is around 56 percent of the ownership of the largest shareholder) there is a closer identification between the interests of the largest shareholder and the interests of the other shareholders, which should improve the value of the firm.

This result is consistent with recent literature that shows a positive influence of the ownership concentration on the performance of the firms in this kind of countries [7173]. These authors stress that the ownership concentration, by giving incentives to the largest shareholders to monitor managers, reduces the agency conflict between managers and shareholders. On the contrary, the lack of relation between the firm's value and $\mathrm{C} 1$ is consistent with the managerial relation rather than the concentrated ownership being the main agency problem in the Anglo-Saxon institutional setting $[27,30]$.

Column (1) in Table 4 also shows an asymmetric effect of the managerial ownership: while in civil-law firms there is a nonlinear relation with the value of the firm, in the commonlaw environment the managerial ownership does not have any significant impact on the firm's value. This result can be explained by institutional issues since managers in the civil-law firms are more identified with shareholders, so that managerial ownership works as a mechanism of corporate control complementary to the ownership concentration. 
Thus, to some extent, in the civil-law firms the managerial ownership replies the effect of the ownership concentration.

Results reported in Column (2) of Table 4 also corroborate the endogeneity of the ownership structure since the ownership concentration is affected by the value of the firm. Thus, there is a mutual interaction between firm's value and the ownership structure. Moreover, the value of the firm has a differential effect on the ownership concentration conditional on the institutional setting: while in civil-law countries the firms with higher market value have more concentrated ownership, in common law firms we detect the opposite relation. In addition, ownership structure depends not only on the value of the firm but also on the financial leverage, growth opportunities, risk, and firm performance. Interestingly, the sign of the impact of financial leverage is different in each institutional setting.

As far as financial decisions are concerned, Column (3) in Table 4 shows that capital structure and ownership structure are taken simultaneously. Once more, the effect of the ownership structure is different in each institutional environment: in civil-law firms both mechanisms are complementary, with positive interaction between them; on the contrary, the capital structure and the ownership structure are alternative mechanisms of control in common law firms. The value of the firm is also related to financial leverage with a negative direction of causality. This result can be explained by the pecking-order theory [41], since firms with more ability to generate internal funds are less leveraged.

All the estimates include time, country, and industry control dummies. We also report the Hausman-Wu test of specification and the average treatment effect on the treated. According to the Hausman test, the possibility of misspecification of the model can be ruled out. The average treatment effect on the treated is always significant and lends support to the rejection of the null hypothesis of no differences between both sub-samples. We also report the $R$ squared coefficient for each equation.

Therefore, our results point at a differential effect of the ownership structure on the value of the firm depending on the legal environment, at the endogeneity of the ownership structure, and at the relation between capital structure and other mechanisms of corporate governance. In order to have a more in-depth view of the relation between ownership concentration and firm's value we perform an additional analysis splitting up the sample conditional on the nature of the largest shareholder: investment manager versus strategic entity.

The results of this analysis are reported in Table 5 and provide interesting insights. As one can see in Column (1) in Table 5 the ownership concentration has a nonlinear effect on the value of the firms whose largest shareholder is a strategic entity. Since strategic entities usually hold a stable stake in the ownership of the firm, this result confirms the duality of alignment versus entrenchment problems related to strategic entities as large shareholders. On the contrary, the ownership concentration in the hand of investment managers has a linear negative impact on the value of the firms. This result can be explained by the short-term orientation of such shareholders, so that too big stakes could destabilize the strategy of the firm $[18,74]$. All the other relations are basically unaffected, which corroborates the fact that the ownership structure is endogeneously determined with the value of the firm and that financial decisions are taken simultaneously with other mechanisms of corporate control.

According to the Hausman-Wu test, the model is not badly specified. The average treatment effect on the treated allows rejecting with a high confidence level the hypothesis that both sub-samples are the same and, therefore, we can accept that the each kind of largest shareholder has specific features. We also report the $R$-squared coefficient for each equation.

The results reported previously raise two questions: the effect of the country development, and the possibility of managerial ownership replicating the effect of ownership concentration. Thus, the estimates in Table 6 shows two specific issues: first, we introduce C1DEV and C1DEV ${ }^{2}$, two interacted variables computed as the product of RICH and both $\mathrm{C} 1$ and $\mathrm{C1}^{2}$. These variables illustrate the specific effect of ownership concentration in the more developed or richer countries. Second, we introduce a cubical effect of the managerial ownership [38].

These new estimates stress the need to control for international issues such as the economic development and the institutional environment. Column (1) in Table 6 shows the asymmetric effect of the largest shareholder stake: a nonlinear relation for civil law firms, and the lack of relation for common law firms. More interestingly, C1DEV and $\mathrm{C} \mathrm{DEV}^{2}$ play a moderating effect (with the opposite influence of $\mathrm{C} 1$ and $\mathrm{C1}^{2}$ ). These results mean that, in the more developed countries, ownership concentration has a U-inverted influence that can counterbalance the influence of $\mathrm{C} 1$ and $\mathrm{Cl}^{2}$. This is in line with some recent research about the differential effects of ownership for less developed European countries [32].

Also according to Column (1) in Table 6, the managerial ownership has a significantly different effect in each legal setting. Whereas in common-law firms managerial ownership does not have any relevant effect on the value of the firm, in civil-law firms there is a cubical relation with three different phases. There is an initial positive influence of managerial ownership on the value of the firm, according to the hypothesis of convergence of interests. Then, the relation turns into a negative one and, after a certain threshold, the relation becomes positive again. These results make sense since, for high enough managerial ownership, there is an identification between shareholders and managers, with a positive influence on the value of the firm.

Once again, the other two key ideas of our research hold too. As shown in column (2), the value of the firm and the capital structure are significant determinants of the ownership structure, so that the ownership structure becomes an endogenous issue. Column (3) reports that both the ownership concentration and the value of the firm have significant influence on the capital structure. The checks for the specification of the model support the validity of the estimates too. 
TABLE 4: System of simultaneous equations estimates: baseline model.

\begin{tabular}{|c|c|c|c|c|c|c|}
\hline & Civil & Common & Civil & Common & Civil & Common \\
\hline & (1) MBE & & (2) HERF & & (3) LEV & \\
\hline LEV & $\begin{array}{c}1.707^{* * *} \\
(0.333)\end{array}$ & $\begin{array}{c}1.302^{* * *} \\
(0.332)\end{array}$ & $\begin{array}{c}0.215^{* * *} \\
(0.043)\end{array}$ & $\begin{array}{l}0970^{* * *} \\
(0.035)\end{array}$ & & \\
\hline MBE & & & $\begin{array}{c}0.118^{* * *} \\
(0.044)\end{array}$ & $\begin{array}{c}-0.744^{* * *} \\
(0.168)\end{array}$ & $\begin{array}{c}-0.549^{* *} \\
(0.284)\end{array}$ & $\begin{array}{c}0.766^{* * *} \\
(0.173)\end{array}$ \\
\hline HERF & & & & & $\begin{array}{c}4.091^{* * *} \\
(0.213)\end{array}$ & $\begin{array}{c}1.030^{* * *} \\
(0.048)\end{array}$ \\
\hline SIZE & $\begin{array}{c}-1.151^{* * *} \\
(0.217)\end{array}$ & $\begin{array}{c}-0,384^{* *} \\
(0.163)\end{array}$ & $\begin{array}{c}-0.170^{* * *} \\
(0.032)\end{array}$ & $\begin{array}{c}-0.284^{* * *} \\
(0.105)\end{array}$ & $\begin{array}{c}0.756^{* * *} \\
(0.092)\end{array}$ & $\begin{array}{c}0.292^{* * *} \\
(0.108)\end{array}$ \\
\hline OPORT & $\begin{array}{l}-0.013 \\
(0.009)\end{array}$ & $\begin{array}{l}-0.007 \\
(0.004)\end{array}$ & $\begin{array}{c}-0.004^{* * *} \\
(0.001)\end{array}$ & $\begin{array}{l}-0.005 \\
(0.004)\end{array}$ & $\begin{array}{c}-0.019^{* *} \\
(0.008)\end{array}$ & $\begin{array}{l}-0.005 \\
(0.004)\end{array}$ \\
\hline RISK & $\begin{array}{c}31.893^{* * *} \\
(5.231)\end{array}$ & $\begin{array}{c}0.013^{* *} \\
(0.006)\end{array}$ & $\begin{array}{c}-3.874^{* *} \\
(1.647)\end{array}$ & $\begin{array}{c}0.010^{* *} \\
(0.005)\end{array}$ & $\begin{array}{l}16.656^{*} \\
(8.262)\end{array}$ & $\begin{array}{c}0.010^{* *} \\
(0.005)\end{array}$ \\
\hline ROA & $\begin{array}{c}26.884^{* * *} \\
(3.295)\end{array}$ & $\begin{array}{c}24.371^{* * *} \\
(1.530)\end{array}$ & $\begin{array}{l}0.849^{* * *} \\
\quad(0.786)\end{array}$ & $\begin{array}{c}18.134^{* * *} \\
(3.424)\end{array}$ & $\begin{array}{c}-3.790^{* * *} \\
(3.315)\end{array}$ & $\begin{array}{c}-18.689^{* * *} \\
(3.517)\end{array}$ \\
\hline $\mathrm{C} 1$ & $\begin{array}{c}-0.034^{* * *} \\
(0.011)\end{array}$ & $\begin{array}{l}-0.008^{*} \\
(0.004)\end{array}$ & & & & \\
\hline $\mathrm{C}^{2}$ & $\begin{array}{c}0.000^{* *} \\
(0.000)\end{array}$ & $\begin{array}{c}0.000 \\
(0.000)\end{array}$ & & & & \\
\hline INS & $\begin{array}{c}-0.047^{* * *} \\
(0.011)\end{array}$ & $\begin{array}{l}-0.000 \\
(0.001)\end{array}$ & & & & \\
\hline $\mathrm{INS}^{2}$ & $\begin{array}{c}0.000^{* * *} \\
(0.000)\end{array}$ & $\begin{array}{l}-0.000 \\
(0.000)\end{array}$ & & & & \\
\hline Country effect & Yes & Yes & Yes & Yes & Yes & Yes \\
\hline Industry effect & Yes & Yes & Yes & Yes & Yes & Yes \\
\hline Year effect & Yes & Yes & Yes & Yes & Yes & Yes \\
\hline Observations & 1176 & 1608 & 1176 & 1608 & 1176 & 1608 \\
\hline Average treatment effect & $-0.1504^{* * *}(0.0062)$ & & $1.2545^{* * *}(0.2082)$ & & $-1.4443 * *(0.7152)$ & \\
\hline Hausman-Wu test & $82.41^{* * *}$ & $66.35^{* * *}$ & $11.36^{* * *}$ & $12.73^{* * *}$ & $27.84^{* * *}$ & $65.97 * * *$ \\
\hline$R^{2}$ & 0.4704 & 0.3410 & 0.1988 & 0.3756 & 0.2964 & 0.2760 \\
\hline
\end{tabular}

Estimated coefficients and (standard deviation) of the systems of simultaneous equations. The endogeneous variables are financial leverage (LEV), MBE (ratio of equity market to book value), and HERF (Herfindahl index of ownership concentration). The exogeneous variables are return on assets (ROA), the size of the firm (SIZE), the growth opportunities (OPORT), the risk of the assets (RISK), the percentage of shares held by the largest shareholder (C1) and the percentage of shares held by the managers (INS). ${ }^{* *},{ }^{* *},{ }^{*}$ stand for significant at $99 \%, 95 \%$, and $90 \%$ confidence levels. The Chow test allow testing the null hypothesis that both estimations are from the same sample. All the estimations include time-dummy variables.

\section{Concluding Remarks}

Recent research in corporate finance based on the agency theory and on the economics of information has tried to explain the interrelations among corporate ownership structure, corporate capital structure, and corporate value. The relevance of the ownership structure (ownership concentration, managerial ownership, and the nature of the largest shareholders) and of the capital structure is due to be two prominent mechanisms of corporate governance that can curb the conflicts of interests inside the firm. Our research assumes that both mechanisms are designed simultaneously in order to achieve the optimal corporate governance. Thus, we follow a growing field of the literature that states that the capital structure and the ownership structure are endogenously determined inside the firm, so that there may be mutual inter-causality.

Our paper is also founded on the Law \& Finance approach, according to which the legal and institutional environment has a significant impact on the corporate control. Whereas in the so-called common-law countries the most important conflict is the one between managers and shareholders, in the civil-law countries the most significant 
TABLE 5: System of simultaneous equations estimates: type of large shareholders (investment managers versus strategic entities).

\begin{tabular}{|c|c|c|c|c|c|c|}
\hline & IM & SE & IM & SE & IM & SE \\
\hline & (1) $\mathrm{MBE}$ & & (2) HER & & (3) LEV & \\
\hline LEV & $1.111^{* * *}$ & $1.629^{* * *}$ & $0.174^{* * *}$ & $0.243^{* * *}$ & & \\
\hline & $(0.343)$ & $(0.360)$ & $(0.043)$ & $(0.084)$ & & \\
\hline MBE & & & $-0.154^{* * *}$ & $-0.146^{* * *}$ & -2.292 & 0.215 \\
\hline & & & $(0.041)$ & $(0.046)$ & $(2.428)$ & $(0.264)$ \\
\hline HERF & & & & & 3.891 & $2.165^{* * *}$ \\
\hline & & & & & $(5.710)$ & $(0.215)$ \\
\hline SIZE & $-0.656^{* * *}$ & $-1.403^{* * *}$ & $-0.103^{* * *}$ & $-0.210^{* * *}$ & 0.001 & $0.739 * * *$ \\
\hline & $(0.194)$ & $(0.247)$ & $(0.026)$ & $(0.056)$ & $(0.681)$ & $(0.079)$ \\
\hline OPORT & -0.061 & $0.146^{* * *}$ & -0.000 & $-0.005^{* * *}$ & -0.058 & 0.007 \\
\hline & $(0.020)$ & $(0.032)$ & $(0.000)$ & $(0.001)$ & $(0.046)$ & $(0.009)$ \\
\hline RISK & 0.079 & $-0.318^{* * *}$ & 0.012 & $0.003^{* *}$ & 0.407 & $-0.009^{*}$ \\
\hline & $(0.088)$ & $(0.082)$ & $(0.013)$ & $(0.001)$ & $(0.420)$ & $(0.005)$ \\
\hline ROA & $23.827 * * *$ & $26.898^{* * *}$ & $3.685^{* *}$ & $3.975^{* * *}$ & 41.075 & $-11.398^{* * *}$ \\
\hline & $(1.624)$ & $(3.445)$ & $(0.945)$ & $(1.256)$ & $(47.507)$ & $(3.452)$ \\
\hline $\mathrm{C} 1$ & -0.034 & $-0.023^{* *}$ & & & & \\
\hline & $(0.026)$ & $(0.011)$ & & & & \\
\hline $\mathrm{C}^{2}$ & -0.000 & $-2 E-04^{*}$ & & & & \\
\hline & $(0.000)$ & $(1 E-04)$ & & & & \\
\hline INS & 0.000 & 0.000 & & & & \\
\hline & $(0.003)$ & $(0.011)$ & & & & \\
\hline INS $^{2}$ & -0.000 & 0.000 & & & & \\
\hline & $(0.000)$ & $(0.000)$ & & & & \\
\hline Country effect & Yes & Yes & Yes & Yes & Yes & Yes \\
\hline Industry effect & Yes & Yes & Yes & Yes & Yes & Yes \\
\hline Year effect & Yes & Yes & Yes & Yes & Yes & Yes \\
\hline Observations & 1575 & 1206 & 1575 & 1206 & 1575 & 1206 \\
\hline Average treatment effect & $-0.2442 * * *(0.0054)$ & & $0.4042 * *(0.2285)$ & & $-0.6499^{* * *}(0.0355)$ & \\
\hline Hausman-Wu test & $75.55^{* * *}$ & $21.33^{* * *}$ & $21.98^{* *}$ & $32.74^{* * *}$ & $10.29 * * *$ & $31.72 * * *$ \\
\hline $\mathrm{R}^{2}$ & 0.4072 & 0.3443 & 0.2698 & 0.2793 & 0.2757 & 0.3077 \\
\hline
\end{tabular}

Estimated coefficients and (standard deviation) of the systems of simultaneous equations. Regressions are run according to the nature of the largest shareholder: investment manager (IM) or strategic entity (IE). The endogeneous variables are financial leverage (LEV), MBE (ratio of equity market to book value) and HERF (Herfindahl index of ownership concentration). The exogeneous variables are return on assets (ROA), the size of the firm (SIZE), the growth opportunities (OPORT), the risk of the assets (RISK), and the percentage of shares held by the largest shareholder (C1) and the percentage of shares held by the managers (INS). ${ }^{* *}, * *, *$ stand for significant at $99 \%, 95 \%$, and $90 \%$ confidence levels. The Chow test allow testing the null hypothesis that both estimations are from the same simple. All the estimations include time-dummy variables.

agency problem arises due to the possible expropriation of minority shareholders by large dominant shareholders.

We analyze the mutual relations between ownership structure, capital structure, and the value of the firm for a sample of 1,130 firms from France, Italy, Portugal, Spain, the Netherlands, Belgium, Greece, Germany, Japan, Austria, Norway, Sweden, Finland, Australia, USA, and UK between 2000 and 2006. We use the simultaneous equations method. Our results suggest significant differences conditional on the legal and institutional setting. In the civil-law countries there is a U-shaped relation between ownership concentration and the value of the firm: a negative relation for low levels of concentration, and a positive relation for high enough concentration. On the contrary, in the commonlaw countries there is a positive effect of the ownership concentration on the value of the firm.

This asymmetric influence can be explained on the basis of the entrenchment and convergence of the largest shareholders' interests in the civil law firms. In this environment, the ownership is more concentrated so the main conflict is the one between dominant shareholders and minority shareholders. In the civil-law setting, we also find that the 
TABLE 6: Systems of simultaneous equations estimates: cubical effect of managerial ownership.

\begin{tabular}{|c|c|c|c|c|c|c|}
\hline & Civil & Common & Civil & Common & Civil & Common \\
\hline & (1) $\mathrm{MBE}$ & & (2) HER & & (3) LEV & \\
\hline LEV & $1.886^{* * *}$ & $0.658^{*}$ & $0.224^{* * *}$ & $-0.211^{* * *}$ & & \\
\hline & $(0.365)$ & $(0.348)$ & $(0.036)$ & $(0.019)$ & & \\
\hline MBE & & & $0.100^{* * *}$ & $-0.289 * * *$ & $-0.419^{* *}$ & $1.370^{* * *}$ \\
\hline & & & $(0.036)$ & $(0.048)$ & $(0.194)$ & $(0.266)$ \\
\hline HERF & & & & & $3.680^{* * *}$ & $4.669 * * *$ \\
\hline & & & & & $(0.170)$ & $(0.313)$ \\
\hline SIZE & $-1.268^{* * *}$ & $-0.287^{*}$ & $-0.177^{* * *}$ & $-0.085^{* * *}$ & $0.742 * * *$ & $0.402 * * *$ \\
\hline & $(0.240)$ & $(0.167)$ & $(0.028)$ & $(0.031)$ & $(0.080)$ & $(0.150)$ \\
\hline OPORT & -0.015 & $-0.011^{* *}$ & $-0.004^{* * *}$ & $-0.003^{* * *}$ & $0.017^{* *}$ & $0.014^{* *}$ \\
\hline & $(0.009)$ & $(0.004)$ & $(0.001)$ & $(0.001)$ & $(0.007)$ & $(0.006)$ \\
\hline RISK & $32.672^{* * *}$ & $0.014^{* *}$ & $-3.351^{* *}$ & $0.004^{* * *}$ & $12.469^{* *}$ & $-0.021^{* * *}$ \\
\hline & $(5.463)$ & $(0.006)$ & $(1.432)$ & $(0.001)$ & $(6.447)$ & $(0.007)$ \\
\hline ROA & $28.524^{* * *}$ & $21.658^{* * *}$ & $1.138^{*}$ & $6.362 * * *$ & $-5.141^{* *}$ & $-30.083^{* * *}$ \\
\hline & $(3.600)$ & $(1.620)$ & $(0.646)$ & $(1.005)$ & $(2.329)$ & $(5.360)$ \\
\hline $\mathrm{C} 1$ & $-0.047^{* * *}$ & $-0.022^{* *}$ & & & & \\
\hline & $(0.014)$ & $(0.010)$ & & & & \\
\hline $\mathrm{C}^{2}$ & $0.000 * * *$ & -0.000 & & & & \\
\hline & $(0.000)$ & $(0.000)$ & & & & \\
\hline C1DEV & $0.042^{* *}$ & 0.0046 & & & & \\
\hline & $(0.019)$ & $(0.013)$ & & & & \\
\hline $\mathrm{C} 1^{2} \mathrm{DEV}$ & $-0.001^{* * *}$ & 0.001 & & & & \\
\hline & $(0.000)$ & $(0.001)$ & & & & \\
\hline INS & $-0.083^{* * *}$ & 0.001 & & & & \\
\hline & $(0.019)$ & $(0.018)$ & & & & \\
\hline INS $^{2}$ & $0.001^{* * *}$ & -0.000 & & & & \\
\hline & $(0.000)$ & $(0.000)$ & & & & \\
\hline $\mathrm{INS}^{3}$ & $-0.000^{* * *}$ & 0.000 & & & & \\
\hline & $(0.000)$ & $(0.000)$ & & & & \\
\hline Country effect & Yes & Yes & Yes & Yes & Yes & Yes \\
\hline Industry effect & Yes & Yes & Yes & Yes & Yes & Yes \\
\hline Year effect & Yes & Yes & Yes & Yes & Yes & Yes \\
\hline Observations & 1176 & 1608 & 1176 & 1608 & 1176 & 1608 \\
\hline Average treatment effect & $-0.2394^{* *}(0.1381)$ & & $0.2739 * *(0.0820)$ & & $-0.5550 * * *(0.1352)$ & \\
\hline Hausman-Wu test & $23.74^{* * *}$ & $29.91^{* * *}$ & $53.82^{* * *}$ & $68.26^{* * *}$ & $36.68^{* * *}$ & $27.93^{* * *}$ \\
\hline$R^{2}$ & 0.3589 & 0.4716 & 0.2345 & 0.2105 & 0.2962 & 0.2758 \\
\hline
\end{tabular}

Estimated coefficients and (standard deviation) of the systems of simultaneous equations. The endogeneous variables are financial leverage (LEV), MBE (ratio of equity market to book value), and HERF (Herfindahl index of ownership concentration). The exogeneous variables are return on assets (ROA), the size of the firm (SIZE), the growth opportunities (OPORT), the risk of the assets (RISK), the percentage of shares held by the largest shareholder (C1), and the percentage of shares held by the managers (INS). $* * *, * *, *$ stand for significant at $99 \%, 95 \%$, and $90 \%$ confidence levels. The Chow test allow testing the null hypothesis that both estimations are from the same simple. All the estimations include time-dummy variables.

degree of development of the country plays a relevant role, since the ownership concentration has an opposite impact in the most and in the least developed countries.

The nature of the largest shareholder also provides interesting insights. Our data show that the entrenchment effect is specially prevailing when the largest shareholder holds a stable stake as most of the strategic entities (i.e., nonfinancial corporations, individual investors, and families) do.

The effect of managerial ownership is also affected by the institutional environment, with a significant influence 
in the civil-law countries and no influence in the commonlaw countries. This result can be explained since in the civillaw setting the managerial ownership and the ownership concentration work as complementary mechanisms of corporate control. A more in-depth analysis shows that this relation is better specified in the civil law countries through a cubic relation. In this way, there is a convergence of interest between shareholders and managers both for low levels and for very high levels of managerial ownership.

Our results also support the double causal relation between the ownership structure and firm's value. This result corroborates the idea of endogeneity by showing that the ownership structure is not only a significant determinant of the value of the firm, but also it is an outcome of the value of the firm.

Finally, we detect an interrelation between financial leverage and ownership structure conditional on the legal environment. Whereas both mechanisms work as complementary mechanisms in the civil law system, they seem to be substituting mechanisms in the common law firms.

\section{Acknowledgments}

This paper has benefited from the comments of two anonymous referees, José López Gracia and the participants in the XIX ACEDE conference held in Toledo (Spain). The authors acknowledge the financial support of the Spanish Ministry of Science and Innovation (ECO2011-29144-C03-01) and that of the Chilean Government (Fondecyt Iniciación no. 11110021). All the remaining errors are our only responsibility.

\section{References}

[1] M. C. Jensen and W. H. Meckling, "Theory of the firm: managerial behavior, agency costs and ownership structure," Journal of Financial Economics, vol. 3, no. 4, pp. 305-360, 1976.

[2] J. J. McConnell and H. Servaes, "Additional evidence on equity ownership and corporate value," Journal of Financial Economics, vol. 27, no. 2, pp. 595-612, 1990.

[3] R. Morck, A. Shleifer, and R. W. Vishny, "Management ownership and market valuation. An empirical analysis," Journal of Financial Economics, vol. 20, pp. 293-315, 1988.

[4] A. Shleifer and R. W. Vishny, "A survey of corporate governance," Journal of Finance, vol. 52, no. 2, pp. 737-783, 1997.

[5] M. Harris and A. Raviv, "The theory of capital structure," Journal of Finance, vol. 46, no. 1, pp. 297-355, 1991.

[6] M. C. Jensen, "Agency costs of free cash flow, corporate finance, and takeovers," American Economic Review, vol. 76, no. 2, pp. 323-329, 1986.

[7] S. A. Ross, "The determinants of financial structure: the incentive signaling approach," Bell Journal of Economics, vol. 8, no. 1, pp. 23-40, 1977.

[8] C. E. Crutchley, M. R. H. Jensen, J. S. Jahera, and J. E. Raymond, "Agency problems and the simultaneity of financial decision making: the role of institutional ownership," International Review of Financial Analysis, vol. 8, no. 2, pp. 177-197, 1999.
[9] H. Demsetz and K. Lehn, "The structure of corporate ownership: causes and consequences," Journal of Political Economy, vol. 93, no. 6, pp. 1155-1177, 1985.

[10] H. Short, "Ownership, control, financial structure and the performance of firms," Journal of Economic Surveys, vol. 8, no. 3, pp. 203-249, 1994.

[11] H. Demsetz and B. Villalonga, "Ownership structure and corporate performance," Journal of Corporate Finance, vol. 7, no. 3, pp. 209-233, 2001.

[12] C. P. Himmelberg, R. G. Hubbard, and D. Palia, "Understanding the determinants of managerial ownership and the link between ownership and performance," Journal of Financial Economics, vol. 53, no. 3, pp. 353-384, 1999.

[13] S. Thomsen, T. Pedersen, and H. K. Kvist, "Blockholder ownership: effects on firm value in market and control based governance systems," Journal of Corporate Finance, vol. 12, no. 2, pp. 246-269, 2006.

[14] C. R. Chen and T. L. Steiner, "Managerial ownership and agency conflicts: a nonlinear simultaneous equation analysis of managerial ownership, risk taking, debt policy, and dividend policy," Financial Review, vol. 34, pp. 119-136, 1999.

[15] G. R. Jensen, D. P. Soldberg, and T. S. Zorn, "Simultaneous determination of insider ownership, debt, and dividend policies," Journal of Financial and Quantitative Analysis, vol. 27, no. 2, pp. 247-263, 1992.

[16] Y. H. Kim, J. C. Rhim, and D. L. Friesner, "Interrelationships among capital structure, dividends, and ownership: evidence from South Korea," Multinational Business Review, vol. 15, no. 3, pp. 25-42, 2007.

[17] S. Bhagat and B. Bolton, "Corporate governance and firm performance," Journal of Corporate Finance, vol. 14, no. 3, pp. 257-273, 2008.

[18] E. Elyasiani and J. Jia, "Distribution of institutional ownership and corporate firm performance," Journal of Banking and Finance, vol. 34, no. 3, pp. 606-620, 2010.

[19] T. H. D. King and M. M. Wen, "Shareholder governance, bondholder governance, and managerial risk-taking," Journal of Corporate Finance, vol. 35, no. 3, pp. 512-531, 2011.

[20] M. H. Cho, "Ownership structure, investment, and the corporate value: an empirical analysis," Journal of Financial Economics, vol. 47, no. 1, pp. 103-121, 1998.

[21] C. Loderer and K. Martin, "Executive stock ownership and performance: tracking faint traces," Journal of Financial Economics, vol. 45, no. 2, pp. 223-225, 1997.

[22] R. La Porta, F. Lopez-De-Silanes, A. Shleifer, and R. W. Vishny, "Legal determinants of external finance," Journal of Finance, vol. 52, no. 3, pp. 1131-1150, 1997.

[23] R. La Porta, F. Lopez-de-Silanes, and A. Shleifer, "Corporate ownership around the world," Journal of Finance, vol. 54, no. 2, pp. 471-517, 1999.

[24] R. La Porta, F. Lopez-De-Silanes, A. Shleifer, and R. Vishny, "Investor protection and corporate governance," Journal of Financial Economics, vol. 58, no. 1-2, pp. 3-27, 2000.

[25] X. Zhou, "Understanding the determinants of managerial ownership and the link between ownership and performance: comment," Journal of Financial Economics, vol. 62, no. 3, pp. 559-571, 2001.

[26] Y. Hu and S. Izumida, "Ownership concentration and corporate performance: a causal analysis with Japanese panel data," Corporate Governance, vol. 16, no. 4, pp. 342-358, 2008.

[27] M. Becht and A. Röell, "Blockholdings in Europe: an international comparison," European Economic Review, vol. 43, no. 4-6, pp. 1049-1056, 1999. 
[28] M. Bianco and P. Casavola, "Italian corporate governance: effects on financial structure and firm performance," European Economic Review, vol. 43, no. 4-6, pp. 1057-1069, 1999.

[29] A. Dyck and L. Zingales, "Private benefits of control: an international comparison," Journal of Finance, vol. 59, no. 2, pp. 537-600, 2004.

[30] R. Morck, D. Wolfenzon, and B. Yeung, "Corporate governance, economic entrenchment, and growth," Journal of Economic Literature, vol. 43, no. 3, pp. 655-720, 2005.

[31] T. Nenova, "The value of corporate voting rights and control: a cross-country analysis," Journal of Financial Economics, vol. 68, no. 3, pp. 325-351, 2003.

[32] S. Estrin, J. Hanousek, E. Kočenda, and J. Svejnar, "The effects of privatization and ownership in transition economies," Journal of Economic Literature, vol. 47, no. 3, pp. 699-728, 2009.

[33] S. Claessens, S. Djankov, and L. H. P. Lang, "The separation of ownership and control in East Asian Corporations," Journal of Financial Economics, vol. 58, no. 1-2, pp. 81-112, 2000.

[34] M. Bianchi, M. Bianco, and L. Enriques, "Pyramidal groups and the separation between ownership and control in Italy," in The Control of Corporate Europe, F. Barca and M. Becht, Eds., Oxford University Press, Oxford, UK, 2001.

[35] D. J. Santana and I. Aguiar, "El último propietario de las empresas cotizadas españolas (1996-2002)," Cuadernos de Economía y Dirección de la Empresa, vol. 26, pp. 47-72, 2006.

[36] S. R. Kole, "Measuring managerial equity ownership: a comparison of sources of ownership data," Journal of Corporate Finance, vol. 1, no. 3-4, pp. 413-435, 1995.

[37] S. Kole, "Managerial ownership and firm performance: incentive or rewards?" Advances in Financial Economics, vol. 24, pp. 119-149, 1996.

[38] A. De Miguel, J. Pindado, and C. De La Torre, "Ownership structure and firm value: new evidence from Spain," Strategic Management Journal, vol. 25, no. 12, pp. 1199-1207, 2004.

[39] R. J. Zeckhauser and J. Pond, "Sustaining investment, discretionary investment, and valuation: a residual funds study of the paper industry," in Asymmetric Information, Corporate Finance and Investment, R. G. Hubbard, Ed., pp. 127-148, The University of Chicago Press, Chicago, Ill, USA, 1990.

[40] C. G. Holderness, R. S. Kroszner, and D. P. Sheehan, "Were the good old days that good? Changes in managerial stock ownership since the great depression," Journal of Finance, vol. 54, no. 2, pp. 435-469, 1999.

[41] S. C. Myers and N. S. Majluf, "Corporate financing and investment decisions when firms have information that investors do not have," Journal of Financial Economics, vol. 13, no. 2, pp. 187-221, 1984.

[42] T. Pedersen and S. Thomsen, "Economic and systemic explanations of ownership concentration among Europe's largest companies," International Journal of the Economics of Business, vol. 6, no. 3, pp. 367-381, 1999.

[43] D. K. Denis and J. J. McConnell, "International corporate governance," Journal of Financial and Quantitative Analysis, vol. 38, no. 1, pp. 1-36, 2003.

[44] D. Li, F. Moshirian, P. K. Pham, and J. Zein, "When financial institutions are large shareholders: the role of macro corporate governance environments," Journal of Finance, vol. 61, no. 6, pp. 2975-3007, 2006.

[45] U. Schröder and A. Schrader, "The changing role of banks and corporate governance in Germany: evolution towards the market?" in Competition and Convergence in Financial Markets. The German and Anglo-American Models, S. W. Black and M. Moersch, Eds., pp. 17-33, Elsevier, Amsterdam, The Netherlands, 1998.

[46] L. A. Bebchuk and M. J. Roe, "A Theory of path dependence in corporate ownership and governance," Stanford Law Review, vol. 52, no. 1, pp. 127-170, 2000.

[47] J. Hanousek and A. Shamshur, "A stubborn persistence: is the stability of leverage ratios determined by the stability of the economy?" Journal of Corporate Finance, vol. 17, no. 5, pp. 1360-1376, 2011.

[48] S. Grossman and O. D. Hart, "Corporate financial structure and managerial incentives," in Financial Markets and Financial Crises, J. J. McCall, Ed., pp. 107-140, The University of Chicago Press, Chicago, Ill, USA, 1982.

[49] W. S. Kim and E. H. Sorensen, "Evidence of the impact of the agency costs of debt on corporate debt policy," Journal of Financial and Quantitative Analysis, vol. 21, no. 2, pp. 131144, 1986.

[50] L. Friend and L. Lang, "An empirical test of the impact of managerial self-interest on corporate capital structure," Journal of Finance, vol. 43, no. 2, pp. 271-281, 1988.

[51] G. W. Fenn and N. Liang, "Corporate payout policy and managerial stock incentives," Journal of Financial Economics, vol. 60, no. 1, pp. 45-72, 2001.

[52] L. Chen and X. L. Zhao, "Understand the roles of the market-to-book ratio and profitability in corporate financing decision," 2005, http://www.afajof.org/pdfs/2005/program/ uabstract/a156_corporate_finance.pdf.

[53] K. H. Chung and S. W. Pruitt, "A simple approximation of Tobin's q," Financial Management, vol. 23, no. 3, pp. 70-74, 1994.

[54] M. Frank and V. Goyal, "Capital structure decisions: which factors are really important," Working Paper. SSRN, 2004.

[55] E. García Meca and J. P. Sánchez Ballesta, "Una aproximación empírica al efecto de los activos intangibles sobre la estructura financiera en la empresa española," Revista Europea de Dirección y Economía de la Empresa, vol. 18, no. 1, pp. 51-72, 2009.

[56] R. Rajan and L. Zingales, "What do we know about capital structure? Some evidence from international data," The Journal of Finance, vol. 50, pp. 1421-1460, 1995.

[57] L. Laeven and R. Levine, "Complex ownership structures and corporate valuations," Review of Financial Studies, vol. 21, no. 2, pp. 579-604, 2008.

[58] B. Maury, "Family ownership and firm performance: empirical evidence from Western European corporations," Journal of Corporate Finance, vol. 12, no. 2, pp. 321-341, 2006.

[59] B. Maury and A. Pajuste, "Multiple large shareholders and firm value," Journal of Banking and Finance, vol. 29, no. 7, pp. 18131834, 2005.

[60] J. López-Gracia and F. Sogorb-Mira, "Testing trade-off and pecking order theories financing SMEs," Small Business Economics, vol. 31, no. 2, pp. 117-136, 2008.

[61] S. Ghosh and R. Sensarma, "Does monetary policy matter for corporate governante: firm level evidence fron India," in Advances in Financial Economics, M. Hirschey, K. John, and A. K. Makhija, Eds., vol. 13 of Corporate Governance and Firm Performance, pp. 327-353, Emerald Group Publishing Limited, 2004.

[62] T. B. Greif and R. R. Thom, "Intangible assets in the valuation process: a small business acquisition study," Journal of Academy of Business and Economics, vol. 8, no. 4, 2008. 
[63] K. John, L. Litov, and B. Yeung, "Corporate governance and risk-taking," Journal of Finance, vol. 63, no. 4, pp. 1679-1728, 2008.

[64] M. Konishi and Y. Yasuda, "Factors affecting bank risk taking: evidence from Japan," Journal of Banking and Finance, vol. 28, no. 1, pp. 215-232, 2004.

[65] International Monetary Fund, World Economic Outlook Database, 2012.

[66] A. S. Hadi, "Identifying multiple outliers in multivariate data," Journal of the Royal Statistical Society, vol. 54, pp. 761-771, 1992.

[67] A. S. Hadi, "A modification of a method for the detection of outliers in multivariate samples," Journal of the Royal Statistical Society, vol. 56, pp. 393-396, 1994.

[68] J. A. Hausman, "Specification tests in econometrics," Econometrica, vol. 46, no. 6, pp. 1251-1271, 1978.

[69] A. Abadie, D. Drukker, J. L. Herr, and G. W. Imbens, "Implementing matching estimators for average treatment effects in Stata," Stata Journal, vol. 4, no. 3, pp. 290-311, 2004.

[70] R. La Porta, F. Lopez-de-Silanes, A. Shleifer, and R. Vishny, "Investor protection and corporate valuation," Journal of Finance, vol. 57, no. 3, pp. 1147-1170, 2002.

[71] P. Kapopoulos and S. Lazaretou, "Corporate ownership structure and firm performance: evidence from Greek firms," Corporate Governance, vol. 15, no. 2, pp. 144-158, 2007.

[72] F. Perrini, G. Rossi, and B. Rovetta, "Does ownership structure affect performance? Evidence from the Italian market," Corporate Governance, vol. 16, no. 4, pp. 312-325, 2008.

[73] L. Renneboog and P. G. Szilagyi, How Relevant is Dividend Policy under Low Shareholder Protection? Tilburg Law and Economic Center Discussion paper 2006-019, 2006.

[74] E. Elyasiani, J. J. Jia, and C. X. Mao, "Institutional ownership stability and the cost of debt," Journal of Financial Markets, vol. 13, no. 4, pp. 475-500, 2010. 


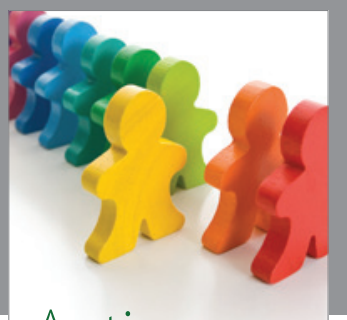

Autism

Research and Treatment
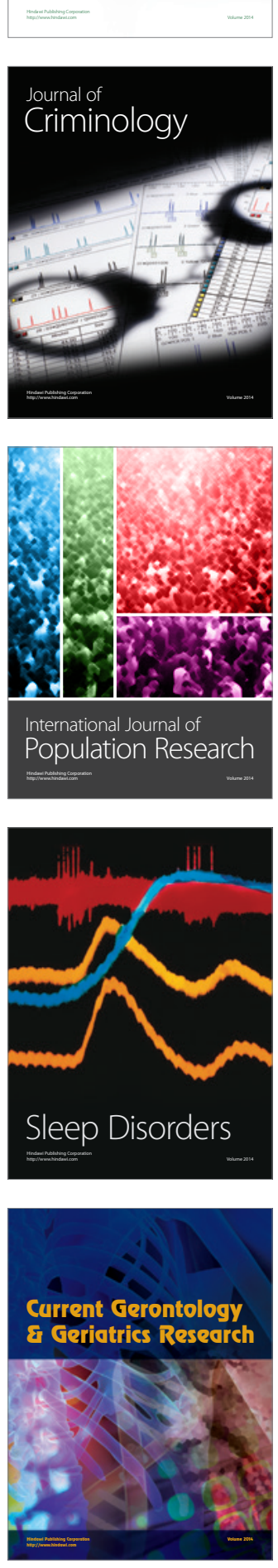
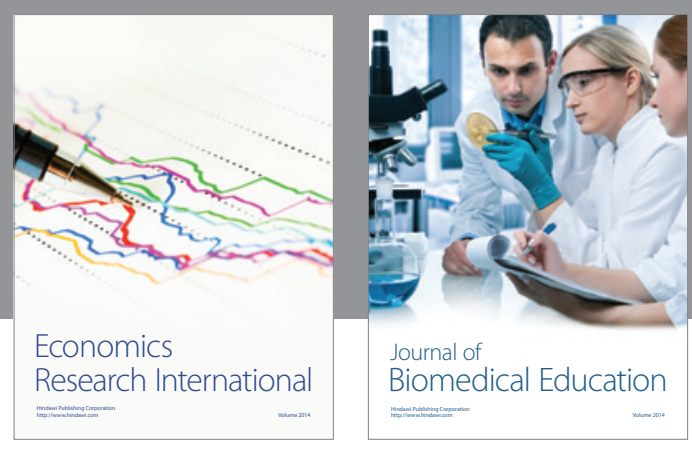

Journal of

Biomedical Education

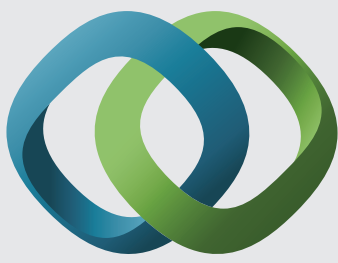

\section{Hindawi}

Submit your manuscripts at

http://www.hindawi.com
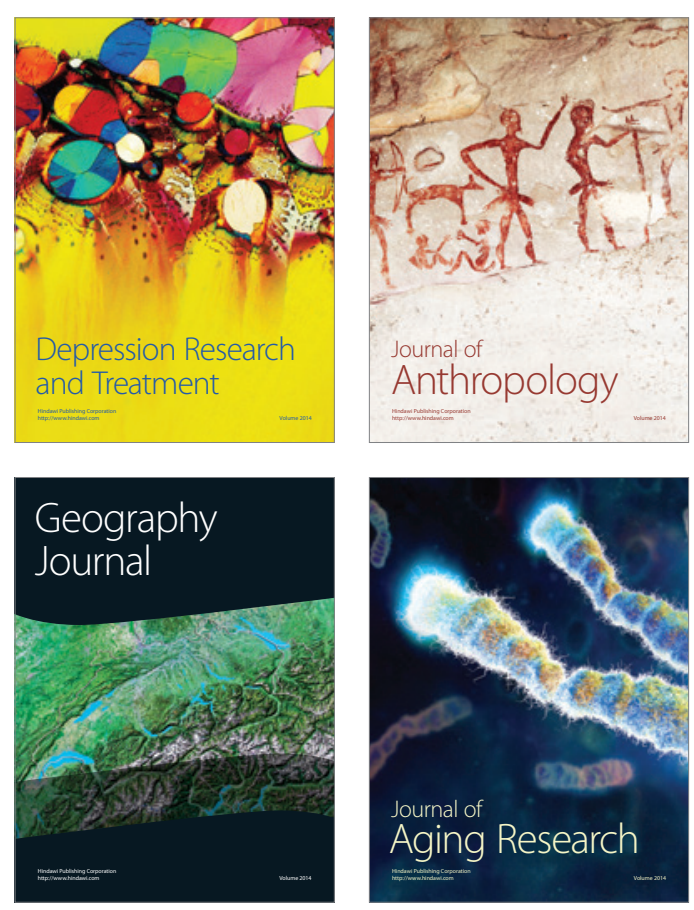

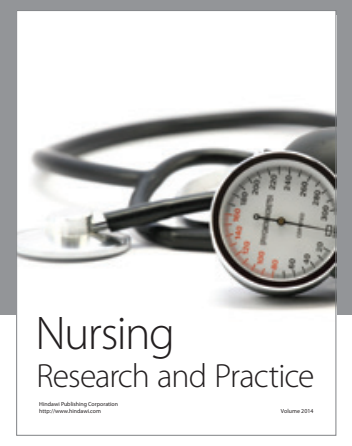

Nursing

Research and Practice

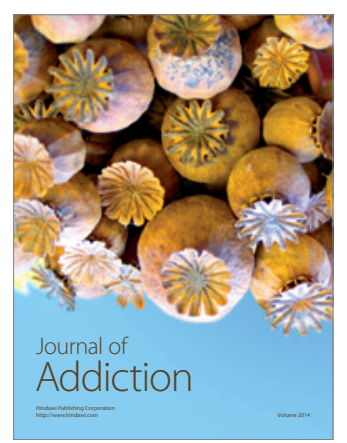

Child Development

Research

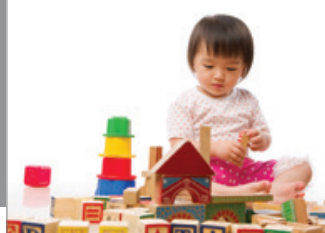

迥
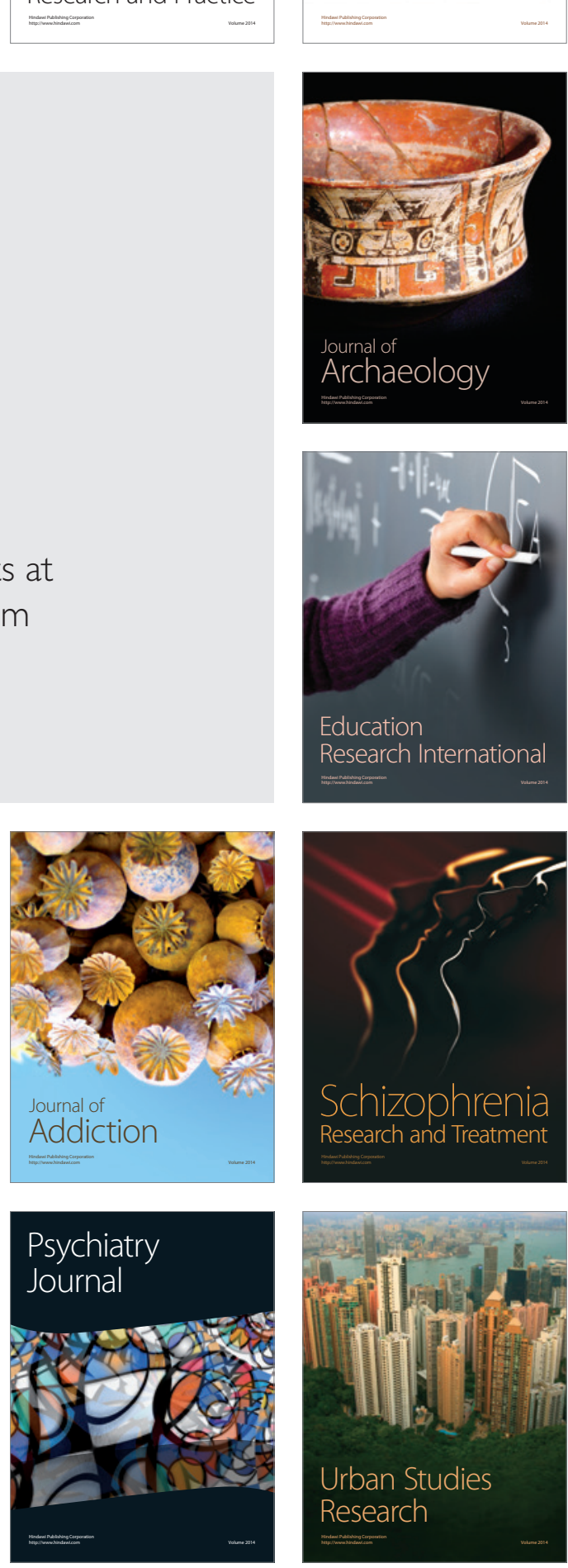